\title{
POLIGAMI DALAM PERSPEKTIF KADER MUSLIMAH WAHDAH ISLAMIYAH MAKASSAR
}

\section{POL YGAMY FROM MUSLIMAH WAHDAH ISLAMIYAH IN MAKASSAR'S CADRES' PERSPECTIVE}

\author{
Iskandar \\ Sekolah Tinggi Ilmu Islam dan Bahasa Arab (STIBA) Makassar \\ Email: iskandarkato@stiba.ac.id \\ Nuraeni Novira \\ Sekolah Tinggi Ilmu Islam dan Bahasa Arab (STIBA) Makassar \\ Email: nuraeni@stiba.ac.id

\section{Eka Syahriani} \\ Sekolah Tinggi Ilmu Islam dan Bahasa Arab (STIBA) Makassar \\ Email: ekasyahriani@stiba.ac.id
}

\section{Aswar}

STKIP Muhammadiyah Barru

Email: aswaralgowi@gmail.com

\begin{tabular}{ll}
\hline Keywords : & \multicolumn{1}{c}{ ABSTRACT } \\
\cline { 2 - 3 } Concept of Polygamy, Muslimah & This study aimed to determine the concept of polygamy in Islam and to \\
& identify polygamy from the perspective of the Muslimah Wahdah \\
& Islamiyah's cadres in Makassar. The problems that the authors raise in \\
& this study are; First, what is the concept of polygamy in Islam. Second, \\
& what is the perspective of Muslimah Wahdah Islamiyah Makassar's \\
& cadres on polygamy. To find answers to these problems, the author \\
& employed a quantitative approach which is designed as survey research \\
& using a questionnaire for data collection. Then the understanding of the \\
& results of the analysis is interpreted descriptively. The results of the \\
& study found that the perspective of Muslimah Wahdah Islamiyah's \\
& cadres in Makassar on polygamy can be seen based on two things, \\
& namely the level of knowledge and understanding of the Muslimah \\
& Wahdah Islamiyah's cadres in Makassar towards polygamy which is in \\
& the medium category and the level of agreement of statements regarding \\
& the perceptions and attitudes of Muslimah Wahdah Islamiyah Makassar's \\
cadres against polygamy which is classified as positive and falls into the & "approved" category \\
\hline Kata kunci : & Penelitian ini bertujuan untuk mengetahui konsep poligami \\
Konsep poligami, Kader Muslimah, \\
Wahdah Makassar \\
dalam Islam dan mengetahui poligami dalam perspektif kader \\
Muslimah Wahdah Islamiyah Makassar. Permasalahan yang \\
penulis angkat dalam penelitian ini yaitu; Pertama, bagaimana \\
konsep poligami dalam Islam. Kedua, bagaimana perspektif kader
\end{tabular}


Muslimah Wahdah Islamiyah Makassar terhadap poligami. Untuk mendapatkan jawaban dari permasalahan tersebut, penulis menggunakan metode pendekatan kuantitatif yang dirancang sebagai sebuah penelitian survei yang menggunakan kuesioner untuk pengumpulan datanya. Kemudian pemahaman terhadap hasil analisis diinterpretasikan secara deskriptif. Hasil penelitian ditemukan bahwa perspektif kader Muslimah Wahdah Islamiyah Makassar terhadap poligami dapat diketahui berdasarkan pada dua hal yaitu tingkat pengetahuan dan pemahaman kader Muslimah Wahdah Islamiyah Makassar terhadap poligami yang termasuk dalam kategori sedang dan tingkat persetujuan dari pernyataan-pernyataan mengenai persepsi dan sikap kader Muslimah Wahdah Islamiyah Makassar terhadap poligami yang tergolong positif dan masuk dalam kategori yang "disetujui".

Diterima: 16 April 2020; Direvisi: 21 Juli 2020; Disetujui: 26 Oktober 2020; Tersedia online: 18 Desember 2020.

How to cite : Iskandar, I., Novira, N., Syahriani, E., Aswar, A. (2020). Poligami dalam Perspektif Kader Muslimah Wahdah Islamiyah Makassar. NUKHBATUL 'ULUM: Jurnal Bidang Kajian Islam, 6 (2), 329-353. https://doi.org/10.36701/nukhbah.v6i2.129

\section{PENDAHULUAN}

Poligami adalah fenomena kehidupan yang terjadi di sekitar kita. Istilah poligami sering terdengar ditelinga masyarakat, namun tidak banyak di antara mereka yang dapat menerima keadaan ini $^{1}$. Walaupun banyak kita dengarkan tentang praktik poligami, namun belum ada data resmi yang ditampilkan dari pihak yang berkompeten seperti Kantor Urusan Agama (KUA), atau Biro Pusat Statistik (BPS) Indonesia. Selain itu, juga belum didapatkan data secara akurat tentang praktik poligami di internal (kader) Wahdah Islamiyah. Survei pemuda muslim di Indonesia diketahui masih cukup konservatif memegang nilai-nilai agama Islam. Tapi mayoritas pemuda muslim ternyata menolak poligami. Burhanuddin Muhtadi pun sebagai direktur Lembaga Survei Indonesia (LSI) menuturkan bahwa sebanyak 52, 9 persen pemuda muslim menolak poligami, sementara 32, 9 persen yang sangat menentang poligami².

Selanjutnya, menurut UU No.1 tahun 1974, disebutkan bahwa perkawinan merupakan ikatan lahir batin antara seorang pria dengan seorang wanita sebagai suami istri dengan tujuan membentuk keluarga (rumah tangga) yang bahagia dan kekal berdasarkan Ketuhanan Yang Maha Esa ${ }^{3}$. Pada prinsipnya dalam UU No.1 Tahun 1974 Tentang Perkawinan, Indonesia

\footnotetext{
${ }^{1}$ Ardhian, dkk.Poligami Dalam Hukum Islam Dan Hukum Positif Indonesia Serta Urgensi Pemberian Izin Poligam Di Pengadilan Agama. Privat Law Vol. III No 2 Juli-Desember 2015, h. 100-107.

${ }^{2}$ Burhanuddin Muhtadi. "Mayoritas Pemuda Muslim Menolak Poligami". DetikNews, (Diakses, 25/11/2020).

${ }^{3}$ Lihat Pasal 1 UU No.1 Tahun 1974 tentang Perkawinan.
} 
menganut asas monogami seperti yang terdapat dalam Pasal 3 yang menyatakan bahwa "Seorang pria hanya boleh mempunyai seorang istri, dan seorang istri hanya boleh mempunyai seorang suami." Namun, dalam UU No.1 Tahun 1974 Tentang Perkawinan Pasal 4 juga menyatakan bahwa "Dalam hal seorang suami akan beristri lebih dari seorang, maka ia wajib mengajukan permohonan kepada pengadilan tempat tinggalnya" ${ }^{4}$. Dengan demikian, seorang laki-laki boleh memiliki dua atau tiga atau empat istri. Kebolehan beristri lebih dari seorang ini tentunya memiliki alasan dan syarat-syarat yang harus dipenuhi. Di Indonesia, syarat-syarat akan kebolehan itu telah diatur dalam Pasal 4 Ayat 2 UU No.1 Tahun 1974.

Selain itu, ada tiga syarat yang dapat dijadikan dasar pengajuan beristri lebih dari seorang (poligami): Pertama, istri tidak dapat menjalankan kewajibannya sebagai istri; Kedua, istri mendapat cacat badan atau penyakit yang tidak diharapkan lagi kesembuhannya; Ketiga, tidak dapat melahirkan keturunan. Sehubungan dengan ini, Islam telah mengajak dan menganjurkan pernikahan. Rasūlullāh saw. menikah sehingga pernikahan adalah sunahnya. Dikatakan bahwa barang siapa yang menolak sunah ini, maka tidak termasuk golongannya. Dalam hadis Bukhari dari Sa'īd ibn Jubair ra. berkata: ${ }^{5} \mathrm{Ibnu}$ 'Abbās ra. berkata kepadaku, “Apakah Engkau telah menikah?” Aku menjawab, "belum," Dia berkata, "Kalau begitu menikahlah, karena sebaik-baik umat ini adalah yang paling banyak istrinya." Ibnu Hajar al-'Asqalāni mengatakan tentang maksud dari hadis ini bahwa sebaik-baik umat Muhammad saw. adalah yang paling banyak istrinya ${ }^{6}$. Dengan demikian, dapat diketahui bahwa dalam hal perkawinan yang paling baik adalah yang paling banyak istrinya, ini berarti bahwa poligami adalah satu-satunya cara untuk memenuhi maksud dari hadis tersebut yaitu memperbanyak istri.

Dalam Islam, poligami bukanlah sesuatu yang dilarang dan tidak juga diwajibkan. Poligami disyariatkan dan hukumnya mubah ${ }^{7}$. Bahkan, 'Abdul 'Aziz ibn Bāz dalam fatwanya mengatakan bahwa poligami hukumnya sunah bagi yang mampu melakukannya. Hal ini sesuai dengan isyarat yang jelas dari Allah swt. dalam Qs. al-Nisā'/4: $3^{8}$. Sejatinya, Rasūlullāh saw. juga melakukannya, beliau menikahi 9 (sembilan) perempuan yang merupakan kekhususan untuknya. Adapun umatnya hanya diperbolehkan berpoligami dengan 4 (empat) perempuan saja. Meskipun sebelum datangnya Islam, jumlah wanita yang dapat dipoligami

${ }^{4}$ Mardani, Hukum Keluarga Islam di Indonesia, h. 95-96.

${ }^{5}$ Bukhari, Sahih Bukhari (Cet.I; Damaskus: Dār Ibnu Kaṡir, 2002), h. 1293.

${ }^{6}$ Ahmad Ibn Ali Ibn Hajar al-Asqalāni,Fathul Bāri, Juz 9 (Riyadh: al-Maktabah alSalafiyyah, 1449), hal 114.

${ }^{7}$ Abdullāh ibn Muhammad al-Ṭayyār, Al- 'Adlu fì al-Ta'addud (Riyadh: Dārul 'Āṣimah, 1992), h. 43.

${ }^{8}$ Departemen Kementrian Agama RI, Al-Qur'an Tajwid dan Terjemah, h. 77. 
berkisar 8, 10 orang atau bahkan lebih dari itu, serta tidak mengindahkan prinsip keadilan, atau semata-mata untuk pemenuhan syahwat belaka9 .

Selain itu, hikmahnya ialah sudah ketetapan Allah swt. di mana populasi kaum lelaki lebih sedikit daripada wanita, dan jika lelaki hanya dibatasi menikahi 1 orang wanita saja, maka akan terjadi penumpukan populasi kaum wanita, dan jika kondisi itu terjadi tanpa pondasi keimanan yang kuat, maka potensi perbuatan zina akan merajalela ${ }^{10}$. Untuk itu, dengan poligami, seseorang dapat menahan pandangannya dan menjaga kemaluannya serta dapat mewujudkan cita-cita Islam yaitu memperbanyak keturunan sehingga menambah jumlah kaum muslimin di seluruh dunia ${ }^{11}$. Dari sini tampak bahwa poligami membawa manfaat yang sangat besar untuk laki-laki maupun perempuan dan keseluruhan umat muslim.

Dalam karya ilmiah Mușțafā ibn al-'Adawy, beliau menuliskan hadishadis yang menunjukkan anjuran poligami. Di antaranya, hadis yang menjelaskan tentang sebaik-baik perhiasan adalah wanita salihah, ${ }^{12}$ hadis tentang anjuran menikahi wanita penyayang dan subur, ${ }^{13}$ dan hadis yang menjelaskan tentang hubungan badan suami isteri adalah sedekah ${ }^{14}$. Dalil-dalil tersebut, pada esensinya menunjukkan akan kebolehan bahkan anjuran poligami. Namun, kebolehan dan anjuran tersebut berlaku jika seorang laki-laki mampu berlaku adil kepada istri-istrinya, jika ia merasa aman dari fitnah istri-istrinya dan tidak mengabaikan hak-hak Allah swt. serta tidak disibukkan dari beribadah kepada Allah swt. disebabkan oleh istri-istrinya itu ${ }^{15}$.

Sederetan dalil-dalil di atas, juga memberikan ruang seluas-luasnya kepada para laki-laki muslim untuk melakukan poligami sebagai salah satu sarana ibadah dan sekaligus jalan untuk menyalurkan hasratnya secara halal. Tidak perlu terbelenggu dengan syarat keadilan karena sesungguhnya syariat ini diturunkan Allah karena Allah Maha Mengetahui bahwa hal ini bisa dijalankan oleh hambanya. Walaupun konsep keadilan ini tentunya tetap harus diperhatikan dan dilaksanakan oleh yang berpoligami. Abdullāh ibn Muhammad al-Ṭayār

${ }^{9}$ Mukran H. Usman, \& Akhmad Hanafi Dain Yunta, "Koreksi Hukum Islam Terhadap Hukum Jahiliah", BUSTANUL FUQAHA: Jurnal Bidang Hukum Islam 1, no. 1 (2020): h.5.

${ }^{10}$ Saguni, M. K., \& Syandri, S, "Meluruskan Beberapa Persepsi tentang Poligami (Tafsir Surah al-Nisa Ayat 3 dan 129)", NUKHBATUL 'ULUM: Jurnal Bidang Kajian Islam 4, no. 2 (2018): h. 170.

${ }^{11}$ Abu Abdul Rahmān, Faḍlu Ta'addud al-Zaujāt (Cet.I; Riyadh: Dārul Manār, 1991), h. $18-19$.

${ }^{12}$ Abul Husain Muslim ibn al-Hajjāj, Sahih Muslim, juz 1 (Cet.I; Riyadh: Dārun Toyyibah, 2006), h. 585.

${ }^{13}$ Ibnu Hibbān, Sahih Ibn Hibbān (Cet.I; Beirut: Dārul Ma’rifah, 2004), h. 1102.

${ }^{14}$ Abul Husain Muslim ibn al-Hajjāj, Sahih Muslim, juz 1, h. 447-448.

${ }^{15}$ Muștafā ibn al-'Adawy, Jāmi' Ahkam al-Nisā' (Cet.I; Kairo: Dār ibn 'Affān, 1999), h. 441-442. 
menjelaskan bahwa adil yang dimaksud yaitu dalam hal muamalah, pemberian nafkah, pergaulan dan persetubuhan. Adapun dalam hal perasaan, maka ini tidak termasuk karena merupakan di luar kehendak manusia dan tidaklah seseorang dibebani jika melebihi batas kemampuannya, dan keadilan ini yang dikecualikan oleh Allah swt. ${ }^{16}$. Rahman sendiri menyebutkan bahwa konsep keadilan dalam Al-Qur'an memuat prinsip kesetaraan, kejujuran dan keikhlasan, tidak terkecuali pada aspek pembahasan tentang poligami ${ }^{17}$.

Berdasarkan dalil-dalil atau argumentasi yang telah disebutkan di atas juga tampak bahwa dalam agama Islam, syariat poligami itu ada. Di Indonesia, ketentuan poligami juga telah diatur dalam UU No.1 Tahun 1974 tentang perkawinan, sehingga ketika seseorang menghadapi kasus poligami seharusnya ini bukanlah suatu hal yang aneh. Namun, kenyataan yang kita temukan bahwa praktik poligami ditolak oleh kebanyakan orang. Alasan mengapa terjadi penolakan karena dianggap bahwa praktik poligami hanya sebagai ajang untuk melampiaskan syahwat laki-laki, poligami merugikan perempuan, menambah masalah keluarga dan merusak tatanan masyarakat.

Di Indonesia, poligami menjadi masalah yang sensitif untuk dibicarakan. Kalaupun diangkat dalam masyarakat, biasanya hanya tentang keburukan dari poligami tersebut yang dibahas. Kasus poligami di Indonesia ada yang berhasil dan ada yang gagal. Banyaknya kasus poligami yang gagal membuat kebanyakan orang merasa khawatir, sehingga menghindari dan menghalangi praktik poligami karena dianggap menimbulkan perpecahan yang berujung pada perceraian. Oleh karena itu, ketika ada praktik poligami yang berjalan baik-baik saja tanpa ada masalah, masyarakat masih tetap memberikan asumsi yang buruk, mencela dan memboikot karena telah tertanam dalam diri bahwa poligami itu buruk.

Fakta sosial ini dapat dilihat dari rekapitulasi data dari Komnas Anti Kekerasan terhadap Perempuan yang telah mencatat kasus perceraian yang diproses di Pengadilan Agama. Berdasarkan alasan yang terungkap, pada tahun 2015 terdapat 9.506 kasus perceraian disebabkan poligami ${ }^{18}$. Selain itu, ada beberapa kasus poligami di Indonesia yang menjadi sorotan dan menuai banyak celaan dari masyarakat. Persoalan tentang poligami ini terutama disangkutpautkan dengan para ulama dan pemuka agama. Di antaranya adalah praktik poligami yang dilakukan oleh dai terkenal yaitu 'Abdullāh Gymnastiar atau yang lebih dikenal dengan sebutan "Aa Gym."

\footnotetext{
${ }^{16}$ Departemen Kementrian Agama RI, Al-Qur'an Tajwid dan Terjemah, h. 99.

${ }^{17}$ Rahman, R. A., "Konsep Keadilan dalam Alquran”, NUKHBATUL'ULUM: Jurnal Bidang Kajian Islam 2, no. 1 (2016): h. 174.

${ }^{18}$ Komnas Anti Kekerasan Terhadap Perempuan. Catatan Tahunan tentang Kekerasan Terhadap Perempuan. 6 Maret 2015.
} 
Pada tahun 2006, setelah Aa Gym mengumumkan akan berpoligami, banyak di antara masyarakat yang memboikotnya, beliau dianggap menyakiti istri pertamanya dengan menikah lagi. Walaupun beliau sendiri mengatakan bahwa apa yang dilakukannya bukan untuk menyakiti istrinya melainkan sebaliknya, dan apa yang dilakukannya adalah sesuatu yang dibolehkan dalam Islam. Dikabarkan bahwa setelah kejadian itu, omset bisnis yang dijalaninya menurun drastis dan kunjungan pada pondok pesantrennya pun berkurang, meskipun setelah diwawancarai, pihak Aa Gym menyangkal berita tersebut dan mengatakan bahwa semuanya berjalan normal seperti biasa. Namun, tayangan televisi pada saat itu menjadi saksi saat ceramah Aa Gym sepi pengunjung. Setelah tahun 2011 diketahui bahwa Aa Gym dan istri pertamanya bercerai, tetapi pada tahun 2012 mereka kembali rujuk ${ }^{19}$.

Kasus poligami yang lain adalah dari tokoh agama, Arifin Ilham. Kemesraan yang biasa ia bagikan di media sosial bersama para istrinya menuai pro dan kontra dalam masyarakat. Meskipun yang tampak dari keluarga ini adalah kebahagiaan, tetapi tetap banyak orang yang menghujat dan memberikan komentar miring karena telah berpoligami ${ }^{20}$. Kasus lainnya yaitu dari tokoh agama, Al-Habsyi yang bercerai dari istri pertamanya pada tahun 2016 lantaran berpoligami tanpa sepengetahuan istrinya ${ }^{21}$. Masih sangat banyak kasus poligami yang lain yang ada di Indonesia baik yang tercatat di Pengadilan maupun yang tidak terdata. Dari fenomena tersebut, praktik poligami di Indonesia telah tampak di sana-sini, dan menuai stigma yang cenderung negatif di masyarakat.

Secara khusus di Makassar, praktik poligami juga dilakukan oleh sebagian orang, tidak terkecuali oleh pengurus dan kader Wahdah Islamiyah yang merupakan salah satu ormas Islam yang didirikan di Kota Makassar Provinsi Sulawesi Selatan. Ormas Wahdah Islamiyah sendiri telah memiliki lembaga LP2KS (Lembaga Pernikahan dan Pembinaan Keluarga Sakinah) yang bertugas untuk melaksanakan program-program keluarga sakinah. Lembaga inilah yang bertanggung jawab dalam hal pernikahan kader Wahdah Islamiyah, tidak terkecuali pernikahan poligami. Sejak Wahdah Islamiyah berdiri pada tahun 1998 yang pada saat itu masih berbentuk yayasan, dan pada tahun 2002 beralih menjadi organisasi massa ${ }^{22}$ sampai sekarang, sudah ada beberapa kader

19 Desika Pemita, "Madu dan Cobaan Pernikahan Aa Gym dan Teh Ninih", https://m.liputan6.com (10 Mei 2019).

20 Wakhid Hasyim, "Arifin Ilham, Poligami dan Paradoks Popularitas", https://m.detik.com(10 Mei 2019).

${ }^{21}$ Dian Anditya Mutiara, "Habsyi ungkapkan alasan menikahi Istri keduanya secara diamdiam", https://wartakota.tribunnews.com(10 Mei 2019).

${ }^{22}$ Samsuddin, S., Iskandar, I., \& Nurshamsul, M., "Pendidikan kader da'i ormas Wahdah Islamiyah melalui halaqah tarbiyah", Ta'dibuna: Jurnal Pendidikan Islam 9, no. 2 (2020): h. 285. 


\section{NUKHBATUL 'ULUM : Jurnal Bidang Kajian Islam}

Vol. 6, No. 2 (2020) : Hal. 329-353

Website: https://journal.stiba.ac.id

ISSN : 2685-7537 (online); 2338-5251 (Printed)

yang mempraktikkan poligami. Ada yang diketahui belum berhasil hingga akhir dan ada pula yang masih bertahan hingga sekarang. Tentunya praktik poligami kader Wahdah Islamiyah dibangun di atas ilmu syar' $i$ yang memadai, dan diperoleh dari forum-forum kecil bernama "halaqah tarbiyah"23.

Praktik poligami yang gagal maupun yang berhasil sampai sekarang tentunya menuai pandangan dan sikap yang berbeda-beda dari para kader Wahdah Islamiyah. Selain contoh-contoh praktik poligami yang mereka ketahui dari sesama kader maupun dari kasus lain yang ada, pengetahuan atau ilmu yang mereka ketahui tentang teori poligami tentunya juga sangat mempengaruhi pandangan dan sikap mereka jika diperhadapkan pada praktik poligami. Dengan demikian, dalam penelitian ini penulis merasa perlu mengkaji pandangan dan sikap kader Wahdah Islamiyah terhadap poligami, terkhusus kepada kader Muslimah Wahdah Islamiyah Makassar.

Sebelumnya, kader Muslimah Wahdah Islamiyah Makassar, sejatinya dikenali berhijab dan bercadar. Aswah melalui penelitiannya, mengkategotikan jilbab dan/atau hijab kader Muslimah Wahdah Islamiyah Makassar menjadi level 1 hingga 4, dan untuk level 4 ialah pakaian syar' $i$ atau bercadar, sehingga memiliki pola interaksi unik ${ }^{24}$. Sejatinya pola interaksi wanita bercadar dalam masyarakat di Kota Makassar terbagi 2 (dua), yakni pola interaksi yang bersifat fleksibel dan eksklusif (terbatas) ${ }^{25}$. Namun, dalam kelompok kecilnya, pola komunikasi Muslimah Wahdah Islamiyah Makassar sebetulnya menerapkan pola komunikasi persuasif dan informatif ${ }^{26}$. Dengan demikian, penelitian terhadap komunitas tersebut memiliki tantangan tersendiri, terlebih bila menyoal "poligami".

Berdasarkan uraian latar belakang di atas, maka penulis mengangkat pokok permasalahan yaitu bagaimana kader Muslimah Wahdah Islamiyah Makassar memandang praktik poligami. Dari permasalahan pokok tersebutlah, maka dapat dirumuskan substansi masalah yang dijadikan acuan dalam pembahasan kajiannya, yakni, "Bagaimana pandangan kader Muslimah Wahdah Islamiyah Makassar terhadap poligami?" Untuk itu, tujuan umum dari penelitian ini tidak lain untuk mengetahui konsep poligami dalam Islam dan

${ }^{23}$ Chaplin, C., "Salafi Islamic piety as civic activism: Wahdah Islamiyah and differentiated citizenship in Indonesia', Citizenship studies 22, no. 2 (2018): h. 216-17.

${ }^{24}$ Aswah, S. R., "Antara Ideal dan Praktek: Transformasi Spiritual Anggota Perempuan Berdasarkan Nilai-Nilai Keperempuanan Wahdah Islamiyah. ETNOSIA: Jurnal Etnografi Indonesia 2, no. 2 (2017): h. 188-191.

${ }^{25}$ Ramdani, F., \& Aswar, A., "Hablun Minannas Wanita Bercadar (Studi Fenomenologi Interaksi Sosial Wanita Bercadar di Kecamatan Manggala Makassar)", NUKHBATUL 'ULUM: Jurnal Bidang Kajian Islam 6, no. 1 (2020): h. 105.

${ }^{26}$ Sari, H., "Pola Komunikasi Daiyah dalam Pembinaan Keagamaan di Muslimah Wahdah Islamiyah Daerah Makassar', NUKHBATUL 'ULUM: Jurnal Bidang Kajian Islam 4, no. 1 (2018): h. 59 
secara khusus untuk mengetahui pandangan kader Muslimah Wahdah Islamiyah Makassar terhadap poligami.

Metode yang digunakan dalam penelitian ini adalah pendekatan kuantitatif dengan rancangan dalam bentuk survei yang menggunakan kuesioner untuk pengumpulan datanya ${ }^{27}$. Adapun pemahaman terhadap hasil analisis data dan interpretasinya diuraikan secara deskriptif. Populasi pada penelitian ini adalah kader Muslimah Wahdah Islamiyah di Kota Makassar dengan menghitung ukuran sampel yang dilakukan dengan menggunakan teknik Slovin. Rumus Slovin dipakai guna mendapatkan jumlahnya sampel yang harus representatif agar hasil penelitian dapat digeneralisasikan dan perhitungannya pun tidak memerlukan tabel jumlah sampel, namun dapat dilakukan dengan rumus dan perhitungan sederhana.

Rumus Slovin ini biasa digunakan dalam penelitian survei di mana biasanya jumlah sampel besar sekali, sehingga diperlukan sebuah formula untuk mendapatkan sampel yang sedikit tetapi dapat mewakili keseluruhan populasi. Rumus Slovin disajikan sebagai berikut:28

$$
\mathbf{n}=\frac{\mathrm{N}}{1+\mathrm{N}(\mathrm{e})^{2}}
$$

Keterangan Rumus:

$\mathrm{n} \quad=$ Jumlah sampel minimal

$\mathrm{N}=$ Populasi

e = error margin (tingkat kesalahan pengambilan sampel yang masih bisa ditolerir, dalam penelitian ini mengambil 6,5\%)

Pada penelitian ini, jumlah populasi kader Muslimah Wahdah Islamiyah di Kota Makassar adalah 2029 orang. Adapun jumlah sampelnya dilakukan penghitungan dengan error margin $6,5 \%$ sebagai berikut:

$$
\begin{aligned}
& \mathbf{n}=\frac{2029}{1+2029(0,065)^{2}} \\
& \mathbf{n}=\frac{2029}{1+2029(0,0042)} \\
& \mathbf{n}=\frac{2029}{9,5218}
\end{aligned}
$$

${ }^{27}$ Rully Indrawan dan Poppy Yaniawati, Metodologi Penelitian. Kuantitatif, Kualitatif, dan Campuran untuk Manajemen, Pembangungunan dan Pendidikan, (Refika Aditama, 2017), h. 54.

${ }^{28}$ Anwar Hidayat, "Cara Hitung Rumus Slovin Besar Sampel", Official Website of Anwar Hidayat, http://www.statistikian.com/2017/12/hitung-rumus-slovin-sampel.html (16 Desember 2017). 


$$
\mathbf{n}=213,08
$$

\section{Jumlah sampel 213 orang)}

Untuk menentukan siapa saja yang akan dijadikan responden dalam penelitian ini maka digunakan metode acak (random). Instrumen yang digunakan dalam penelitian ini berupa kuesioner. Kuesioner yang disebarkan kepada responden terpilih terdiri dari tiga blok yakni Blok Karakteristik Personal, Blok Pengetahuan dan Pemahaman Kader Muslimah Wahdah Islamiyah Makassar Terhadap Poligami, dan Blok Persepsi dan Sikap Kader Muslimah Wahdah Islamiyah Makassar Terhadap Poligami. Adapun penjelasan rinci dua blok (di luar blok identitias responden) yang digunakan dalam penelitian ini adalah sebagai berikut:

1. Blok Pengetahuan dan Pemahaman Kader Muslimah Wahdah Islamiyah Makassar Terhadap Poligami. Blok ini diukur berdasarkan pengetahuan dan pemahaman responden terhadap poligami. Alat ukur ini terdiri dari beberapa pernyataan yang memiliki 3 kemungkinan jawaban yaitu ya, tidak dan raguragu, yang dianalisis dengan metode:

$$
\begin{aligned}
& \mathrm{PH}=\mathrm{X} / \mathrm{Y} \times 100 \% \\
& \text { Keterangan : } \\
& \mathrm{X}=\text { Jumlah Frekuensi } \\
& \mathrm{Y}=\text { Jumlah Sampel } \\
& \mathrm{PH}=\text { Persentase Hasil }
\end{aligned}
$$

Seluruh jawaban dari blok pengetahuan dan pemahaman responden terhadap poligami setelah dirata-ratakan, menunjukkan tingkat pengetahuan dan pemahaman responden terhadap poligami. Berikut ini nilai interval yang menentukan tingkat pengetahuan dan pemahaman responden terhadap poligami:

$$
\begin{aligned}
& \text { Tinggi }=\text { Angka } 125-185 \\
& \text { Sedang }=\text { Angka } 63-124 \\
& \text { Rendah }=\text { Angka } 0-62
\end{aligned}
$$

2. Blok Persepsi dan Sikap Kader Muslimah Wahdah Islamiyah Makassar Terhadap Poligami. Blok ini mengukur tentang pandangan dan sikap responden terhadap poligami, terbagi dalam dua bentuk pernyataan, yaitu pernyataan favorable dan unfavorable. Jawaban dari tiap itemnya diukur dengan menggunakan skala Likert dengan kriteria penilaian sebagai berikut: 
Tabel 1. Pilihan Jawaban dan Kriteria Penilaian Blok Pandangan dan Sikap Responden

\begin{tabular}{lcc}
\hline \multirow{2}{*}{ Pilihan Jawaban } & \multicolumn{2}{c}{ Item } \\
\cline { 2 - 3 } & Favorable & Unfavorable \\
\hline Sangat Setuju & 5 & 1 \\
\hline Setuju & 4 & 2 \\
\hline Netral & 3 & 3 \\
\hline Tidak Setuju & 2 & 4 \\
\hline Sangat Tidak Setuju & 1 & 5 \\
\hline
\end{tabular}

Penghitungan yang digunakan adalah Skala Likert. Misalnya, diuji mengenai tingkat persetujuan responden terhadap praktik poligami dimana ada 185 responden yang memberikan jawaban pada kuesioner.

Berikut contoh rangkuman hasil penilaian 185 responden tersebut:

1. Responden yang menjawab sangat setuju (skor 5) berjumlah 15 orang.

2. Responden yang menjawab setuju (skor 4) berjumlah 30 orang.

3. Responden yang menjawab netral (skor 3) berjumlah 60 orang.

4. Responden yang menjawab tidak setuju (skor 2) berjumlah 50 orang.

5. Responden yang menjawab sangat tidak setuju (skor 1) berjumlah 30 orang.

Untuk mendapatkan skor total dari hasil semua perhitungan ini, maka total jumlah responden yang memilih dikalikan dengan pilihan angka skor Likert:

1. Responden yang menjawab sangat setuju $(5)=15 \times 5=75$

2. Responden yang menjawab setuju (4) $=30 \times 4=120$

3. Responden yang menjawab netral $(3)=60 \times 3=180$

4. Responden yang menjawab tidak setuju (2) $=50 \times 2=100$

5. Responden yang menjawab sangat tidak setuju $(1)=30 \times 1=30$

Jumlah skor total yaitu: $75+120+180+100+30=505$.

Langkah selanjutnya adalah menginterpretasikan skor perhitungan. Agar mendapatkan hasil interpretasi, terlebih dahulu harus diketahui skor tertinggi (X) dan skor terendah (Y) untuk item persetujuan dengan rumus sebagai berikut:

$\mathrm{Y}=$ skor tertinggi likert $\mathrm{x}$ jumlah responden

$\mathrm{X}=$ skor terendah likert $\mathrm{x}$ jumlah responden.

Jumlah skor tertinggi untuk item "Sangat Setuju" adalah 5 x 185 (jumlah responden $)=925$, sedangkan item "Sangat Tidak Setuju" adalah 1 x $185=185$.

Jadi, jika total skor persetujuan responden diperoleh angka 505, maka penilaian interpretasi responden terhadap poligami adalah hasil persetujuan yang dihasilkan dengan menggunakan rumus index \%. 


$$
\text { Rumus Index } \%=\frac{\text { Total skor }}{\mathrm{Y} \times 100}
$$

Sebelum menyelesaikan hasil akhirnya, terlebih dahulu kita harus mengetahui interval (rentang jarak) dan interpretasi persen agar mengetahui penilaian dengan metode mencari interval skor persen (I)

100

$$
\text { Rumus Interval }(\mathrm{I})=\overline{\text { Jumlah Skor (Likert) }}
$$

$$
\text { Maka, } \mathrm{I}=100 / 5=20
$$

Nilai 20 ini adalah intervalnya, jarak terendah 0\% hingga tertinggi $100 \%$. Berikut kriteria interpretasi skornya berdasarkan interval:

1. Angka $0 \%-19,99 \%=$ Sangat tidak setuju

2. Angka $20 \%-39,99 \%=$ Tidak setuju

3. Angka $40 \%-59,99 \%=$ Netral

4. Angka $60 \%-79,99 \%=$ Setuju

5. Angka $80 \%-100 \%=$ Sangat setuju

$$
\begin{aligned}
\text { Penyelesaian akhir } & =\frac{\text { Total skor }}{\mathrm{Y}} \times 100 \\
& =\frac{505}{925} \times 100 \\
& =54.59 \% \text { (berada dalam kategori Netral) }
\end{aligned}
$$

Dari contoh di atas, tingkat persetujuan responden terhadap poligami adalah 54.59\%. Perhitungan dengan skala Likert inilah yang akan peneliti gunakan dalam menghitung hasil keputusan responden dari blok persepsi dan sikap kader Muslimah Wahdah Islamiyah Makassar terhadap poligami.

Adapun sumber data dalam penelitian ini adalah:

1. Data primer yaitu data yang diperoleh langsung dari sumbernya melalui survei yang dilakukan kepada sampel yang telah ditentukan, dalam hal ini dengan menyebarkan kuesioner kepada responden. 
2. Data sekunder yaitu data yang diperoleh dari berbagai sumber, seperti buku, majalah, jurnal, karya ilmiah, internet, dan berbagai sumber lainnya yang terkait dengan objek itu sendiri29.

Metode pengumpulan data dalam penelitian ini adalah:

1. Rancangan Penelitian Survei. Dalam prosedur ini, peneliti survei mengumpulkan data kuantitatif bernomor dengan menggunakan kuesioner atau wawancara ${ }^{30}$. Dalam hal ini, peneliti menggunakan kuesioner.

2. Observasi yaitu pengamatan dan pencatatan yang sistematis.

3. Dokumentasi.

Penelitian ini juga menggunakan berbagai teknik pengolahan dan analisis data yang dilakukan dalam rangka mendeskripsikan atau membahas hasil penelitian, serta mengolah data dan menyajikan dalam bentuk yang sistematis, teratur dan terstruktur serta mempunyai makna yang diklarifikasikan dalam beberapa langkah yaitu:

1. Reduksi Data. Data yang diredukasi adalah: (a) Karakteristik Personal yaitu umur, status pernikahan, jumlah anak, pendidikan terakhir dan lama tarbiyah; (b) Pengetahuan dan Pemahaman terhadap poligami yaitu defenisi, dalil-dalil dan hikmah pembatasan nikah maksimal empat isteri; (c) Persepsi dan Sikap terhadap poligami.

2. Penyajian Data. Data yang telah direduksi dan disajikan masing-masing dalam bentuk diagram batang dan diagram lingkaran dengan menggambarkan persentase masing-masing data.

3. Pengambilan kesimpulan. Kesimpulan yang diambil dari persentase setiap data yang telah disajikan dan secara khusus pada data persepsi dan sikap terhadap pelaksanaan poligami di internal Wahdah Islamiyah.

\section{PEMBAHASAN}

\section{Blok Karakteristik Personal}

Berdasarkan hasil penyebaran kuesioner yang telah dilakukan terhadap sampel penelitian sebanyak 185 orang dalam hal ini adalah kader Muslimah Wahdah Islamiyah Makassar, diperoleh hasil identitas responden yang dibagi ke dalam beberapa bagian sebagai berikut:

\section{Umur}

\footnotetext{
${ }^{29}$ Sugiyono, Memahami Penelitian Kualitatif, (Bandung: Alfabeta, 2012), h. 37.
}

30 John Creswell, Educational Research, Planning, Conducting, and Evaluating Quantitative and Qualitative, terj. Helly Prajitno Soetjipto dan Sri Mulyantini Soetjipto, Riset Pendidikan: Perencanaan, Pelaksanaan, dan Evaluasi Riset Kualitatif \& Kuantitatif, h. 752. 


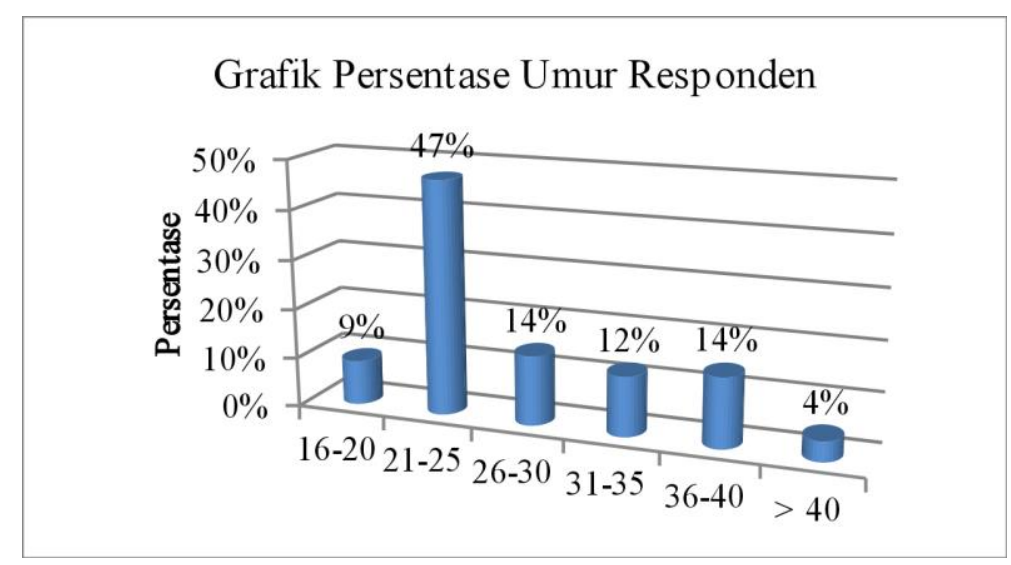

Gambar 1. Grafik Persentase Umur Responden

Dari grafik di atas dapat disimpulkan bahwa responden pada penelitian ini didominasi oleh responden yang berumur 21-25 tahun dengan persentase sebesar $47 \%$ atau sebanyak 100 orang, lalu diikuti oleh responden berumur 26-30 tahun dan 36-40 tahun dengan persentase yang sama yaitu $14 \%$ atau sebanyak 30 orang, kemudian responden yang berumur 31-35 dengan persentase sebesar 12\% atau sebanyak 25 orang, lalu diikuti oleh responden yang berumur 16-20 tahun dengan persentase $9 \%$, selanjutnya diikuti responden berumur ${ }^{-} 40$ tahun dengan presentase $4 \%$ atau sebanyak 9 orang.

\section{Status Perkawinan}

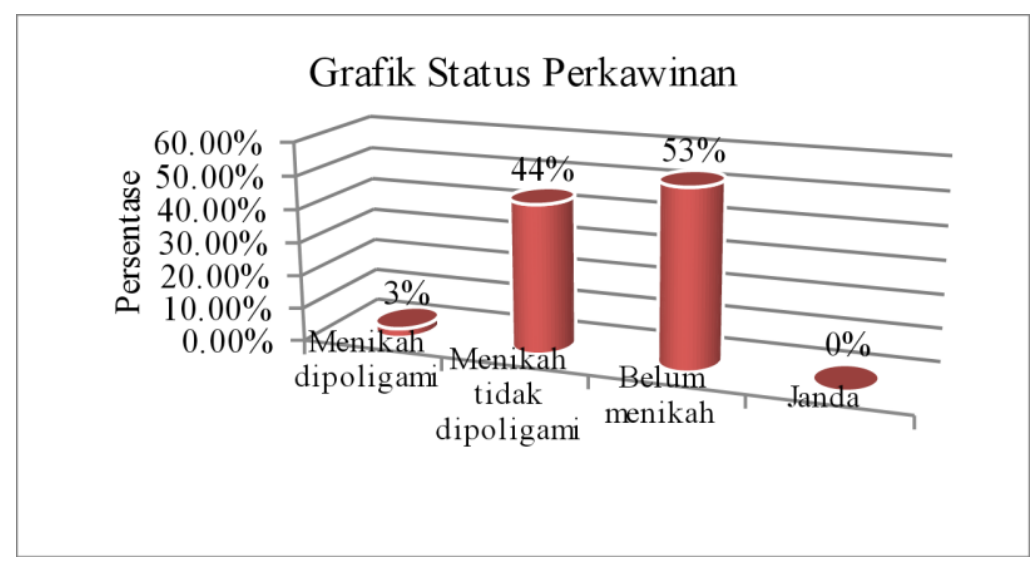

\section{Gambar 2. Grafik Status Perkawinan}

Responden pada penelitian ini didominasi oleh responden yang belum menikah dengan persentase $53 \%$ atau sebanyak 133 orang, kemudian diikuti oleh responden yang menikah tidak dipoligami dengan persentase $44 \%$ atau sebanyak 95 orang, lalu responden yang menikah dipoligami dengan persentase $3 \%$ atau sebanyak 6 orang. Adapun responden dengan status janda $0 \%$ yang berarti tidak ada. 


\section{Jumlah Anak}

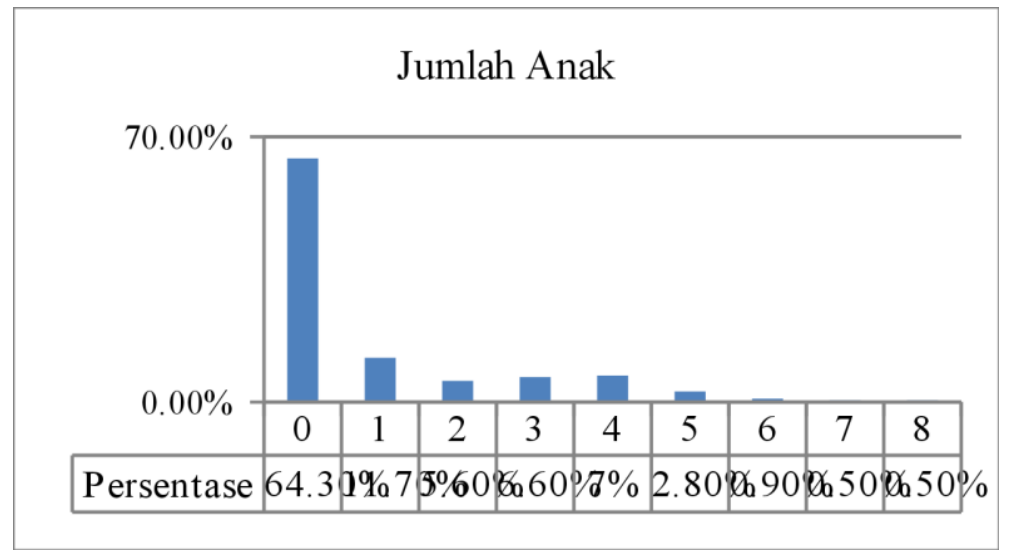

Gambar 3. Jumlah Anak

Responden pada penelitian ini didominasi oleh responden yang tidak memiliki anak yaitu sebanyak 137 orang dengan persentase $64.3 \%$. Berikutnya responden yang memiliki anak satu berjumlah 25 orang dengan persentase $11.7 \%$ yang diikuti oleh responden yang memiliki anak empat berjumlah 15 orang dengan persentase $7 \%$. Selanjutnya diikuti oleh responden yang memiliki anak tiga berjumlah 14 orang dengan persentase $6.6 \%$ lalu responden yang memiliki anak dua berjumlah 12 orang dengan persentase $5.6 \%$.

Secara berurutan diikuti oleh responden yang memiliki anak lima dan enam di mana responden yang memiliki anak lima berjumlah 6 orang dengan persentase $2.8 \%$, sedangkan responden yang memiliki anak enam berjumlah 2 orang dengan persentase $0.9 \%$. Adapun pada urutan terakhir yaitu responden yang memiliki anak tujuh dan delapan yang masing-masing berjumlah satu orang dengan persentase masing-masing $0.5 \%$.

\section{Pendidikan Terakhir}

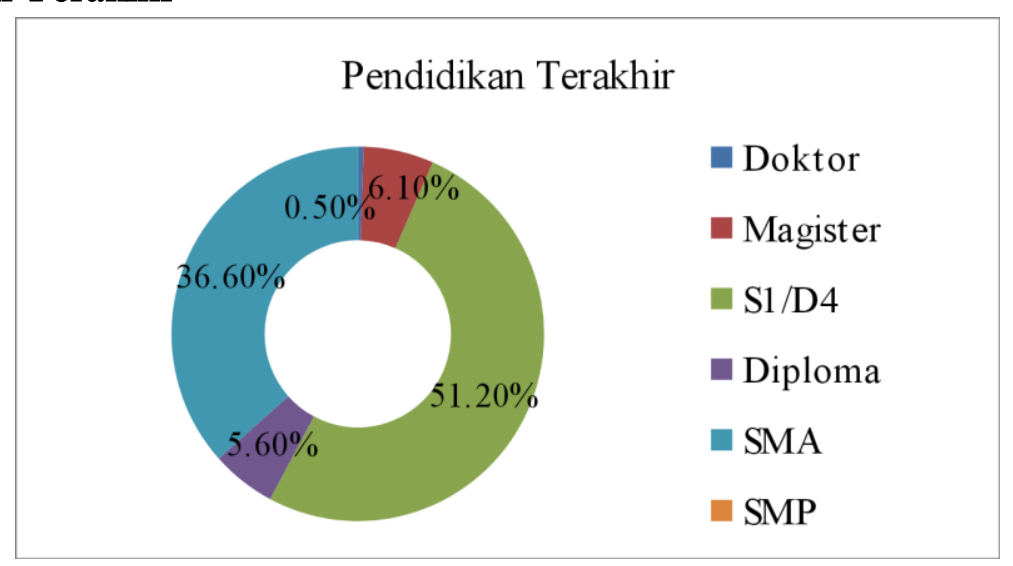

Gambar 4. Pendidikan Terakhir 


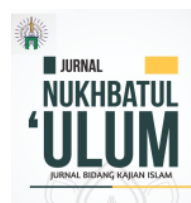

NUKHBATUL 'ULUM : Jurnal Bidang Kajian Islam

Vol. 6, No. 2 (2020) : Hal. 329-353

Website: https://journal.stiba.ac.id

ISSN : 2685-7537 (online); 2338-5251 (Printed)

Responden pada penelitian ini didominasi oleh responden dengan pendidikan terakhir S1/D4 yang berjumlah 109 orang dengan persentase 51.2\% yang diikuti oleh responden dengan pendidikan terakhir SMA yang berjumlah 78 orang dengan persentase $36.6 \%$. Selanjutnya diikuti oleh responden dengan pendidikan terakhir Magister/S2 yang berjumlah 13 orang dengan persentase 6.1\%\% lalu responden dengan pendidikan terakhir Diploma yang berjumlah 12 orang dengan persentase $5.6 \%$, kemudian responden dengan pendidikan terakhir Doktor/S3 yang berjumlah 1 orang dengan persentase $0.5 \%$. Tidak ada responden yang berpendidikan terakhir SMP, SD dan tidak sekolah.

\section{Lama Tarbiyah}

Responden pada penelitian ini didominasi oleh responden yang mengikuti kegiatan tarbiyah Islamiyah selama 5 tahun yang berjumlah 34 orang yang diikuti oleh responden yang mengikuti tarbiyah selama 3 dan 4 tahun yang masing-masing berjumlah 25 orang.

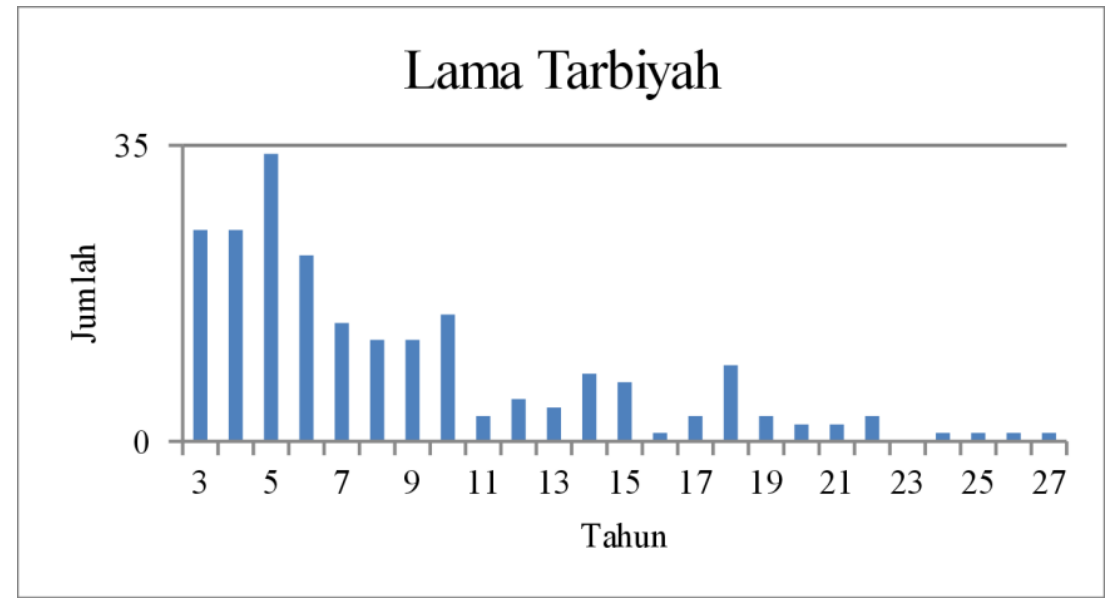

\section{Gambar 5. Lama Tarbiyah}

Selanjutnya diikuti oleh responden dengan lama tarbiyah 6 tahun yang berjumlah 22 orang, kemudian 10 tahun dengan jumlah 15 orang, 7 tahun dengan jumlah 14 orang, 8 dan 9 tahun dengan jumlah masing-masing 12 orang, 18 tahun dengan jumlah 9 orang, 14 tahun dengan jumlah 8 orang, 15 tahun dengan jumlah 7 orang, 12 tahun dengan jumlah 5 orang, 13 tahun dengan jumlah 4 orang, 11, 17, 19 dan 22 tahun dengan jumlah masing-masing 3 orang, 20 dan 21 tahun dengan jumlah masing-masing 2 orang, 16, 24, 25, 26 dan 27 tahun dengan jumlah masing-masing 1 orang.

Blok Pengetahuan dan Pemahaman Kader Muslimah Wahdah Islamiyah Makassar Terhadap Poligami 
Dari 185 sampel kader Muslimah Wahdah Islamiyah Makassar dalam penelitian ini, diperoleh hasil dari blok pengetahuan dan pemahaman responden terhadap poligami yang dibagi ke dalam beberapa bagian sebagai berikut:

\section{Definisi Poligami}

Tingkat pengetahuan dan pemahaman kader Muslimah Wahdah Islamiyah Makassar terhadap definisi poligami disajikan dalam bentuk grafik. Pada tabel grafik di bawah tentang pengetahuan dan pemahaman responden terhadap definisi poligami terdapat tiga pernyataan, pernyataan pertama ditandai dengan huruf A yaitu "Saya mengetahui bahwa kata poligami diambil dari Bahasa Yunani, yaitu poly atau polos berarti banyak dan gamien atau gamos berarti kawin atau perkawinan." Pada pernyataan ini responden yang mengetahuinya sebanyak $30 \%$ atau 56 orang. Adapun yang ragu-ragu bahkan tidak tahu sebanyak 70\% atau 129 orang. Dengan demikian, dapat diketahui bahwa untuk pernyataan ini lebih banyak responden yang tidak mengetahui atau ragu-ragu daripada yang mengetahui dan memahaminya.

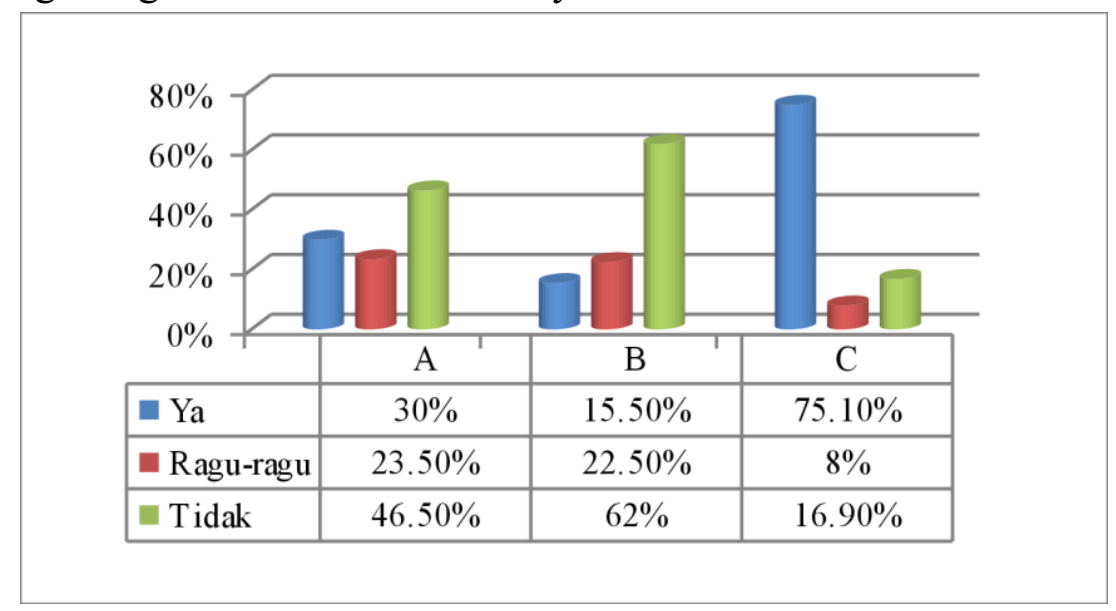

\section{Gambar 6. Definisi Poligami}

Pernyataan kedua pada grafik di atas ditandai dengan huruf B yaitu "Saya memahami bahwa sebenarnya istilah poligami yang selama ini digunakan untuk seorang laki-laki yang memiliki banyak atau lebih dari satu istri adalah kurang tepat, seharusnya namanya adalah poligini, karena istilah ini jarang digunakan dan banyak masyarakat yang kurang mengenalnya maka diaplikasikan dengan istilah poligami." Pada pernyataan ini responden yang mengetahuinya sebanyak $15.50 \%$ atau 29 orang, adapun yang ragu-ragu bahkan tidak tahu sebanyak $84.50 \%$ atau 156 orang. Dengan demikian, dapat diketahui bahwa untuk pernyataan ini lebih banyak responden yang tidak mengetahui atau ragu-ragu daripada yang mengetahui dan memahaminya. 
Pernyataan ketiga pada grafik di atas ditandai dengan huruf C yaitu "Saya mengetahui bahwa poligami dalam Bahasa Arab dimaknai sebagai ta'addud alzaujāt yang berarti berbilang istri." Pada pernyataan ini responden yang mengetahuinya sebanyak $75.10 \%$ atau 139 orang, sementara yang ragu-ragu bahkan tidak tahu sebanyak $24.90 \%$ atau 46 orang. Dengan demikian, dapat diketahui bahwa untuk pernyataan ini lebih banyak responden yang mengetahui dan memahaminya daripada yang ragu-ragu dan tidak mengetahui.

Sejauh ini dapat diambil kesimpulan bahwa hasil dari tingkat pengetahuan dan pemahaman kader Muslimah Wahdah Islamiyah Makassar terhadap definisi poligami berdasarkan nilai rata-rata dari seluruh jawaban "Ya" begitu pun dengan nilai rata-rata dari jawaban "Ragu-ragu" dan "tidak", sehingga diketahui bahwa nilai rata-rata "Ya" adalah 75 sedangkan nilai "Ragu-ragu" dan "Tidak" adalah 110.

\section{Dalil tentang Poligami}

Tingkat pengetahuan dan pemahaman kader Muslimah Wahdah Islamiyah Makassar terhadap dalil poligami disajikan dalam grafik di bawah ini.

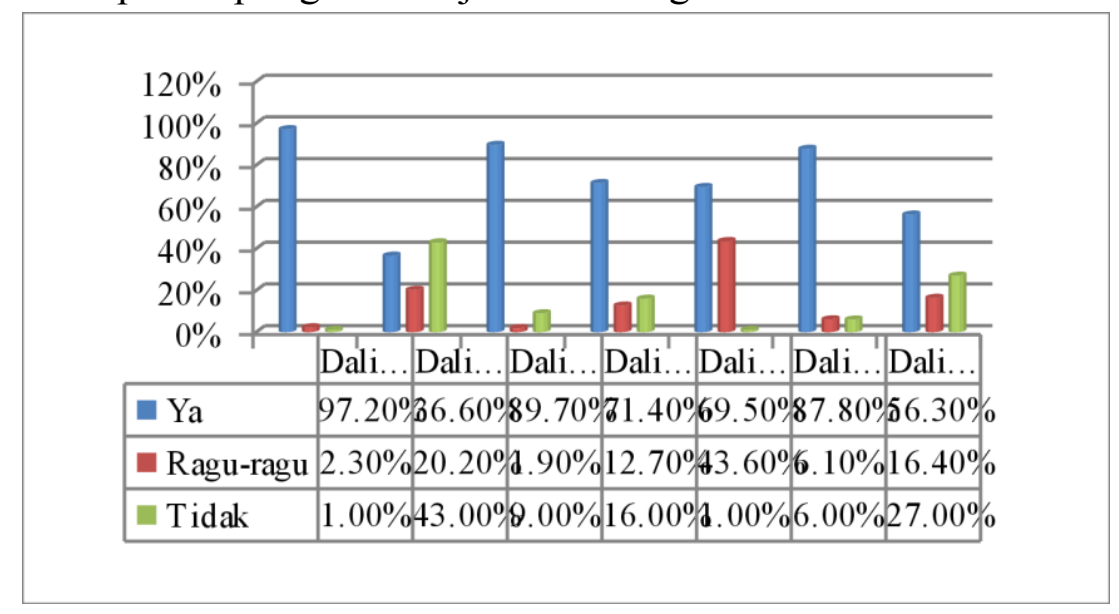

\section{Gambar 7 Dalil tentang Poligami}

Pada grafik di atas tentang pengetahuan dan pemahaman responden terhadap dalil poligami terdapat 7 (tujuh) dalil yang disajikan kepada responden, di mana responden diberikan pertanyaan tentang pengetahuan atau pemahaman mereka mengenai dalil-dalil tersebut. Dalil pertama, tentang kebolehan poligami sampai empat istri dengan persyaratan mampu berbuat adil, dan dalil pertama bahwa responden yang mengetahuinya sebanyak $97.2 \%$ atau 180 orang, sementara yang ragu-ragu bahkan tidak tahu sebanyak $2.8 \%$ atau 5 orang. Dengan demikian, dapat diketahui bahwa dalil ini lebih banyak responden yang mengetahui dan memahaminya daripada tidak mengetahui atau ragu-ragu. 
Dalil kedua, tentang jaminan Rasulullah saw. bahwa yang terbaik dari umatnya adalah yang paling banyak istrinya (empat orang istri), dan dalil kedua bahwa responden yang mengetahuinya sebanyak $36.6 \%$ atau 68 orang, sementara yang ragu-ragu bahkan tidak tahu sebanyak $63.4 \%$ atau 117 orang. Dengan demikian, dapat diketahui bahwa dalil ini lebih banyak responden yang tidak mengetahui atau ragu-ragu daripada mengetahui dan memahaminya.

Dalil ketiga, tentang jaminan Rasulullah saw. bahwa perhiasan dunia yang terbaik adalah wanita salihah, dal dalil ketiga bahwa responden yang mengetahuinya sebanyak $89.7 \%$ atau 166 orang, sementara yang ragu-ragu bahkan tidak tahu sebanyak $10.3 \%$ atau 19 orang. Dengan demikian, dapat diketahui bahwa dalil ini lebih banyak responden yang mengetahui dan memahaminya daripada tidak mengetahui atau ragu-ragu.

Dalil keempat, dari hadis Nabi saw., yang berbunyi:

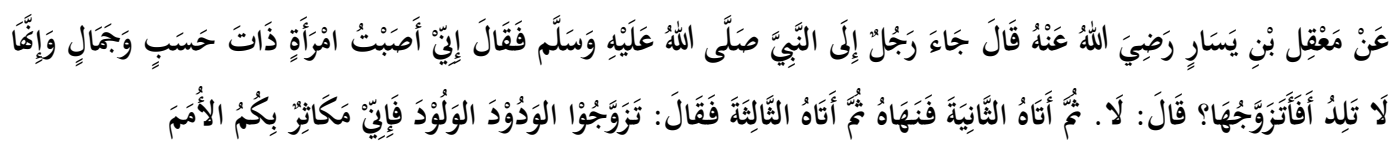

Terjemahnya:

“Dari Ma'qil ibn Yasār ra. berkata, datang seorang laki-laki kepada Nabi saw. dan berkata, "Aku menemukan seorang wanita cantik dan memiliki martabat yang tinggi tetapi ia mandul, apakah aku menikahinya?" Nabi saw. menjawab, "Jangan", kemudian laki-laki itu datang menemui Nabi saw. kedua kalinya dan Nabi saw. tetap melarangnya, kemudian ia menemui Nabi saw. yang ketiga kalinya, maka Nabi saw. berkata, "Nikahilah wanita yang penyayang dan subur, karena aku akan berbangga dengan kalian dihadapan umat-umat yang lain."31

Adapun dalil keempat bahwa responden yang mengetahuinya sebanyak $71.4 \%$ atau 132 orang, sementara yang ragu-ragu bahkan tidak tahu sebanyak $28.6 \%$ atau 53 orang. Dengan demikian, dapat diketahui bahwa dalil ini lebih banyak responden yang mengetahui dan memahaminya daripada tidak mengetahui atau ragu-ragu.

Dalil kelima, dari hadis Nabi saw., yang berbunyi:

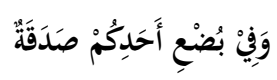

Terjemahnya:

"Dan persetubuhan salah seorang di antara kamu (dengan istrinya) adalah sedekah."32

\footnotetext{
${ }^{31}$ 'Iyadh bin Musa, Ikmal al-Mu'lim bifawaid muslim,(Darul Wafa', 1998), h. 526-527.

${ }^{32}$ Ahmad Assaharanfuri, Badzlu al-Majhud fi Halli Sunan Abi Dawud, (Sheikh Abul Hasan Nadwi Center, India, 2006), h. 273-274.
} 
Adapun dalil kelima bahwa responden yang mengetahuinya sebanyak $69.5 \%$ atau 129 orang, sementara yang ragu-ragu bahkan tidak tahu sebanyak $30.5 \%$ atau 56 orang. Dengan demikian, dapat diketahui bahwa dalil ini lebih banyak responden yang mengetahui dan memahaminya dari pada tidak mengetahui atau ragu-ragu.

Dalil keenam, dari hadis Nabi saw., yang berbunyi:

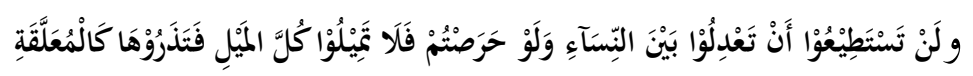

Terjemahnya:

"Dan kamu tidak akan dapat berlaku adil di antara istri-istri(mu), walaupun kamu sangat ingin berbuat demikian, karena itu janganlah kamu terlalu cenderung (kepada yang kamu cintai), sehingga kamu biarkan yang lain terkatung-katung." 33

Adapun dalil keenam bahwa responden yang mengetahuinya sebanyak $87.8 \%$ atau 162 orang, sementara yang ragu-ragu bahkan tidak tahu sebanyak $12.2 \%$ atau 23 orang. Dengan demikian, dapat diketahui bahwa dalil ini lebih banyak responden yang mengetahui dan memahaminya dari pada tidak mengetahui atau ragu-ragu.

Dalil ketujuh, dari hadis Nabi saw., yang berbunyi:

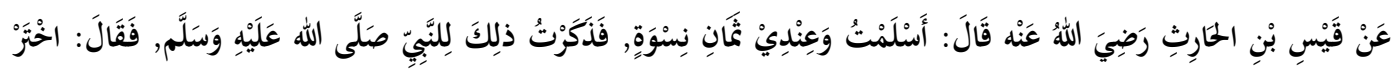

Terjemahnya:

"Dari Qais ibn al-Haris̉ ra. berkata, "Aku masuk Islam sementara aku mempunyai delapan istri. Lalu aku mengadukan hal ini kepada Rasūlullāh saw. Maka beliau menjawab: "Pilihlah empat diantara mereka."34

Adapun dalil ketujuh bahwa responden yang mengetahuinya sebanyak $56.3 \%$ atau 104 orang, sementara yang ragu-ragu bahkan tidak tahu sebanyak $43.7 \%$ atau 81 orang. Dengan demikian, dapat diketahui bahwa dalil ini lebih banyak responden yang mengetahui dan memahaminya dari pada tidak mengetahui atau ragu-ragu.

Sejauh ini dapat diambil kesimpulan sementara hasil dari tingkat pengetahuan dan pemahaman kader Muslimah Wahdah Islamiyah Makassar terhadap dalil-dalil poligami berdasarkan nilai rata-rata dari seluruh jawaban "Ya", begitu pun dengan nilai rata-rata dari jawaban "Ragu-ragu" dan "tidak",

\footnotetext{
${ }^{33}$ 'Iyadh bin Musa, Ikmal al-Mu'lim bifawaid muslim, (Darul Wafa', 1998), Hal. 679Ahmad Assaharanfuri, Badzlu al-Majhud fi Halli Sunan Abi Dawud, (Sheikh Abul Hasan Nadwi Center, India, 2006), h. 586-587.

${ }^{34}$ Ahmad Assaharanfuri, Badzlu al-Majhud fi Halli Sunan Abi Dawud, (Sheikh Abul Hasan Nadwi Center, India, 2006), h. 586-587.
} 
sehingga diketahui bahwa nilai rata-rata "Ya" adalah 134 sedangkan nilai "Raguragu" dan "Tidak" adalah 51.

\section{Hikmah Poligami Dibatasi Empat Istri.}

Tingkat pengetahuan dan pemahaman kader Muslimah Wahdah Islamiyah Makassar terhadap hikmah poligami dibatasi empat istri disajikan dalam grafik di bawah ini.

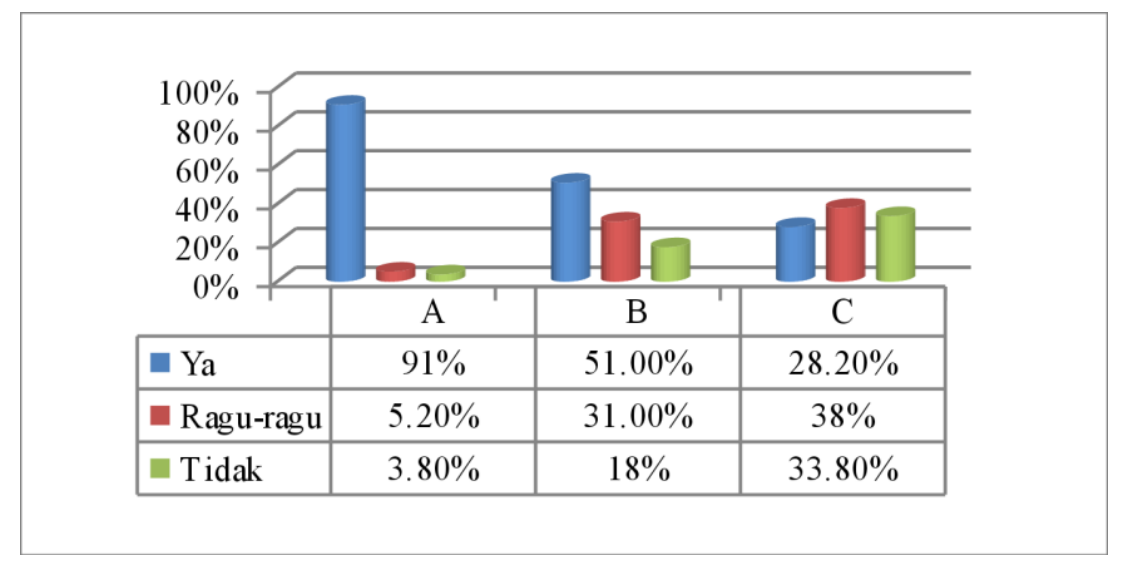

\section{Gambar 8. Hikmah Poligami Dibatasi Empat Istri}

Pada tabel grafik di atas tentang pengetahuan dan pemahaman responden terhadap hikmah poligami dibatasi empat istri terdapat tiga pernyataan, pernyataan pertama ditandai dengan huruf A yaitu "Adanya kaidah umum pada pembatasan bilangan. Ini merupakan perintah Allah swt. yang hanya Allah swt. yang mengetahui hakikatnya." Pada pernyataan ini responden yang mengetahuinya sebanyak $91 \%$ atau 168 orang, sementara yang ragu-ragu bahkan tidak tahu sebanyak $9 \%$ atau 17 orang. Dengan demikian, dapat diketahui bahwa untuk pernyataan ini lebih banyak responden yang mengetahui dan memahaminya daripada yang tidak mengetahui atau ragu-ragu.

Pernyataan kedua pada grafik di atas ditandai dengan huruf B yaitu "Hikmah dari pembatasan ini sesuai dengan perbandingan jumlah laki-laki dan perempuan yaitu 1:4." Pada pernyataan ini responden yang mengetahuinya sebanyak 51\% atau 94 orang, sementara yang ragu-ragu bahkan tidak tahu sebanyak 49\% atau 91 orang. Dengan demikian, dapat diketahui bahwa untuk pernyataan ini lebih banyak responden yang mengetahui dan memahaminya daripada yang tidak mengetahui atau ragu-ragu, meskipun perbedaan angkanya sangat tipis.

Pernyataan ketiga pada grafik di atas ditandai dengan huruf $\mathrm{C}$ yaitu "Sebagian ulama mengatakan bahwa pembatasan ini sesuai dengan kondisi wanita yang pada umumnya mengalami masa haid selama sepekan. Diketahui 
bahwa dalam sebulan ada empat pekan." Pada pernyataan ini responden yang mengetahuinya sebanyak $28.2 \%$ atau 133 orang, sementara yang ragu-ragu bahkan tidak tahu sebanyak $71.8 \%$ atau 52 orang. Dengan demikian, dapat diketahui bahwa untuk pernyataan ini lebih banyak responden yang tidak mengetahui atau ragu-ragu daripada yang mengetahui dan memahaminya.

Sejauh ini dapat diambil kesimpulan bahwa hasil dari tingkat pengetahuan dan pemahaman kader Muslimah Wahdah Islamiyah Makassar terhadap hikmah poligami dibatasi empat istri berdasarkan nilai rata-rata dari seluruh jawaban "Ya", begitu pun dengan nilai rata-rata dari jawaban "Raguragu" dan "tidak", sehingga diketahui bahwa nilai rata-rata "Ya" adalah 105 sedangkan nilai "Ragu-ragu" dan "Tidak" adalah 80.

\section{Blok Persepsi dan Sikap Kader Muslimah Wahdah Islamiyah Makassar Terhadap Poligami}

Berdasarkan pengolahan data, didapatkan jawaban dari responden terkait dengan persepsi dan sikap mereka terhadap poligami yang disajikan dalam tabel berikut.

Tabel 2. Persepsi dan Sikap Kader Muslimah Wahdah Islamiyah Terhadap Praktik Poligami

\begin{tabular}{clcc}
\hline No & \multicolumn{1}{c}{ Persepsi dan Sikap Kader Muslimah WI } & Jumlah & Persentase \\
\hline 1 & $\begin{array}{l}\text { Suami boleh menikah lagi jika istri tidak patuh } \\
\text { kepada suami }\end{array}$ & 692 & $74.8 \%$ \\
\hline 2 & $\begin{array}{l}\text { Saya membolehkan suami jika ingin menikah } \\
\text { lagi jika saya sudah tidak patuh terhadap suami }\end{array}$ & 668 & $72.2 \%$ \\
\hline 3 & $\begin{array}{l}\text { Saya akan mendorong suami untuk menikah lagi } \\
\text { jika saya sudah tidak patuh terhadap suami }\end{array}$ & 653 & $70.59 \%$ \\
\hline 4 & $\begin{array}{l}\text { Suami boleh menikah lagi karena istri sudah } \\
\text { tidak mampu untuk berhubungan seks sebanyak }\end{array}$ & 692 & $74.8 \%$ \\
& yang suami inginkan \\
\hline 5 & $\begin{array}{l}\text { Saya membolehkan suami menikah lagi jika saya } \\
\text { tidak lagi mampu memenuhi keinginan suami } \\
\text { untuk berhubungan seks setiap kali suami } \\
\text { menginginkannya }\end{array}$ & 693 & $74.9 \%$ \\
\hline 6 & $\begin{array}{l}\text { Saya akan mendorong suami untuk menikah lagi } \\
\text { jika saya tidak lagi mampu memenuhi keinginan } \\
\text { suami untuk berhubungan seks setiap kali suami } \\
\text { menginginkannya }\end{array}$ & 681 & $73.6 \%$ \\
\hline 7 & $\begin{array}{l}\text { Suami boleh menikah lagi kalau sudah meminta } \\
\text { persetujuan istrinya }\end{array}$ & 824 \\
\hline 8 & $\begin{array}{l}\text { Saya mengizinkan suami untuk menikah lagi } \\
\text { kalau suami sudah meminta izin kepada saya } \\
\text { terlebih dahulu }\end{array}$ & 730 & $78.9 \%$ \\
\hline
\end{tabular}


Website: https://journal.stiba.ac.id

ISSN : 2685-7537 (online); 2338-5251 (Printed)

\begin{tabular}{|c|c|c|c|}
\hline 9 & $\begin{array}{l}\text { Izin istri adalah hal mutlak yang harus didapat } \\
\text { suami, baru suami boleh menikah lagi }\end{array}$ & 756 & $81.7 \%$ \\
\hline 10 & $\begin{array}{l}\text { Suami boleh menikah lagi kalau sudah } \\
\text { menyampaikan ke istrinya walaupun belum } \\
\text { mendapat izin dari istrinya }\end{array}$ & 623 & $67.35 \%$ \\
\hline 11 & $\begin{array}{l}\text { Suami boleh menikah lagi karena istri yang tidak } \\
\text { dapat memberikan keturunan }\end{array}$ & 799 & $86.37 \%$ \\
\hline 12 & $\begin{array}{l}\text { Saya tentu mengizinkan suami menikah lagi jika } \\
\text { saya tidak dapat memberikannya keturunan }\end{array}$ & 784 & $84.75 \%$ \\
\hline 13 & $\begin{array}{l}\text { Istri yang mandul, tidak membuat suami boleh } \\
\text { beristri lagi walaupun hanya agar bisa punya } \\
\text { anak }\end{array}$ & 584 & $63.1 \%$ \\
\hline 14 & $\begin{array}{l}\text { Saya akan mendorong suami untuk menikah lagi } \\
\text { jika saya tidak mampu memberikannya } \\
\text { keturunan }\end{array}$ & 752 & $81.29 \%$ \\
\hline 15 & $\begin{array}{l}\text { Suami boleh menikah lagi kalau sudah menjamin } \\
\text { akan memenuhi nafkah lahir dan batin seluruh } \\
\text { anak dan istrinya }\end{array}$ & 752 & $81.29 \%$ \\
\hline 16 & $\begin{array}{l}\text { Saya akan merestui suami yang ingin menikah } \\
\text { lagi jika suami sudah menjamin akan memenuhi } \\
\text { nafkah lahir dan batin seluruh anak dan istri } \\
\text { sebagai salah satu syaratnya }\end{array}$ & 762 & $82.37 \%$ \\
\hline 17 & $\begin{array}{l}\text { Saya akan mendorong suami untuk menikah lagi } \\
\text { jika saya merasa suami dapat memenuhi nafkah } \\
\text { lahir dan batin seluruh anak dan istri }\end{array}$ & 697 & $75.35 \%$ \\
\hline 18 & $\begin{array}{l}\text { Suami boleh menikah lagi, apabila suami } \\
\text { menjamin akan berlaku adil terhadap semua istri } \\
\text { dan anaknya }\end{array}$ & 757 & $81.83 \%$ \\
\hline 19 & $\begin{array}{l}\text { Saya akan mengizinkan suami menikah lagi } \\
\text { apabila suami akan berlaku adil terhadap semua } \\
\text { istri dan anaknya }\end{array}$ & 744 & $80.4 \%$ \\
\hline 20 & $\begin{array}{l}\text { Saya akan mendorong suami untuk menikah lagi } \\
\text { jika saya merasa suami dapat berlaku adil } \\
\text { terhadap istri dan anaknya }\end{array}$ & 703 & $76 \%$ \\
\hline 21 & $\begin{array}{l}\text { Suami boleh menikah lagi jika penampilan istri } \\
\text { tidak lagi menarik perhatian suaminya }\end{array}$ & 528 & $57.08 \%$ \\
\hline 22 & $\begin{array}{l}\text { Saya mengizinkan suami menikah lagi jika hal } \\
\text { itu akibat penampilan saya yang tidak lagi } \\
\text { menarik bagi suami }\end{array}$ & 549 & $59.35 \%$ \\
\hline 23 & $\begin{array}{l}\text { Saya akan mendorong suami menikah lagi jika } \\
\text { penampilan saya yang tidak lagi menarik bagi } \\
\text { suami }\end{array}$ & 518 & $56 \%$ \\
\hline 24 & $\begin{array}{l}\text { Suami boleh menikah lagi jika istri mengalami } \\
\text { cacat badan parah dan tidak bisa disembuhkan }\end{array}$ & 752 & $81.29 \%$ \\
\hline 25 & $\begin{array}{l}\text { Saya mengizinkan suami menikah lagi jika hal } \\
\text { itu disebabkan oleh cacat pada tubuh saya tidak } \\
\text { lagi bisa disembuhkan }\end{array}$ & 745 & $80.54 \%$ \\
\hline
\end{tabular}


Website: https://journal.stiba.ac.id

ISSN : 2685-7537 (online); 2338-5251 (Printed)

\begin{tabular}{lllc}
\hline 26 & $\begin{array}{l}\text { Saya akan mendorong suami untuk menikah lagi } \\
\text { jika penyakit pada tubuh saya tidak lagi bisa } \\
\text { disembuhkan }\end{array}$ & 735 & $79.45 \%$ \\
\hline 27 & $\begin{array}{l}\text { Suami boleh menikah lagi jika istri tidak } \\
\text { memenuhi tugasnya mengatur rumah tangga }\end{array}$ & 656 & $70.9 \%$ \\
\hline 28 & $\begin{array}{l}\text { Saya mengizinkan suami menikah lagi jika saya } \\
\text { tidak memenuhi tugas untuk mengatur rumah } \\
\text { tangga }\end{array}$ & 637 & $68.86 \%$ \\
\hline 29 & $\begin{array}{l}\text { Saya akan mendorong suami untuk menikah lagi } \\
\text { jika saya tidak memenuhi tugas untuk mengatur } \\
\text { rumah tangga }\end{array}$ & 616 & $66.59 \%$ \\
\hline 30 & $\begin{array}{l}\text { Pengurus Pusat Wahdah Islamiyah perlu } \\
\text { memberikan instruksi kepada kadernya untuk } \\
\text { berpoligami }\end{array}$ & 567 & $61.29 \%$ \\
\hline 31 & $\begin{array}{l}\text { Suami boleh menikah lagi jika mendapatkan } \\
\text { instruksi dari Pengurus Pusat WI }\end{array}$ & 535 & $57.8 \%$ \\
\hline 32 & $\begin{array}{l}\text { Saya mengizinkan suami untuk menikah lagi jika } \\
\text { mendapatkan instruksi dari Pengurus Pusat WI }\end{array}$ & 531 & $57.4 \%$ \\
\hline 33 & $\begin{array}{l}\text { Saya akan mendorong suami untuk menikah lagi } \\
\text { jika mendapatkan instruksi dari pengurus pusat } \\
\text { WI }\end{array}$ & 524 & $56.64 \%$ \\
\hline
\end{tabular}

Berdasarkan tabel di atas, jika digunakan pendekatan secara matematika sesuai dengan metode perhitungan pada instrumen penelitian terkait dengan upaya-upaya yang disajikan penulis, maka hasil skala rata-rata yang diperoleh adalah sebesar 674 dengan persentase $72.86 \%$.

Artinya, tingkat persetujuan dari pernyataan-pernyataan mengenai persepsi dan sikap mereka terhadap poligami tergolong positif sehingga masuk dalam kategori yang disetujui oleh para kader Muslimah Wahdah Islamiyah Makassar. Oleh karena itu, dapat diasumsikan bahwa kader Muslimah Wahdah Islamiyah Makassar menyetujui praktik poligami untuk dilakukan.

\section{KESIMPULAN}

Perspektif kader Muslimah Wahdah Islamiyah Makassar terhadap poligami adalah mereka memandang sebagai bagian dari syariat Islam dan sudah setuju untuk dilaksanakan secara internal di organisasi Wahdah Islamiyah. Dari hasi penelitian ini pula diperlukan penyamaan perspektif tentang peran dan fungsi gender di masyarakat agar tidak terjadi polemik. Sementara itu, bagi para penentang poligami (aliran fenimisme radikal) yang berkeyakinan bahwa anjuran poligami dalam Islam mengandung unsur diskriminasi, subordinasi dan marginalisasi terhadap kaum perempuan, bahkan dalam beberapa kondisi dapat membuka peluang terjadinya kekerasan terhadap kaum perempuan. Untuk itu, hasil penelitian ini menunjukkan kekeliruan prasangka kelompok penentang 
poligami tersebut. Adapun dari hasil penelitian ini seyogianya dikembangkan kembali bentuk penelitian survei yang serupa dan terkini kepada para pemudi dan wanita yang sudah bersuami secara umum agar diperoleh persepsi terbarukan tentang poligami di kalangan wanita di Indonesia.

\section{DAFTAR PUSTAKA}

Abu Abdillah al-Bukhari. (2002). Sahih Bukhari (Revition). Damaskus: Dār Ibnu Kasiir.

Al-Adawi, Mustafa bin. (1999). Jami Ahkam an-Nisa'. Cet.I; Kairo: Dar ibnu Affan.

Al-Asqalāni, Ahmad Ibn Ali Ibn Hajar. (1449 H). Fathul Bāri, Juz 9. Riyadh: alMaktabah al-Salafiyyah.

Al-Hajjaj, Abul Husain Muslim ibn. (2006). Sahih Muslim. Riyadh: Darun Thoyyibah.

Al-Ṭayyār, Abdullāh ibn Muhammad. (1992). Al-'Adlu fi al-Ta'addud. Riyadh: Dār al-'Āșimah, 1992.

Ardhian, R. F., Anugrah, S., \& Bima, S. (2015). Poligami dalam Hukum Islam dan Hukum Positif Indonesia Serta Urgensi Pemberian Izin Poligam di Pengadilan Agama. PRIVAT LAW II, 3(2).

Assaharanfuri, Ahmad. (2006). Badzlu al-Majhud fi Halli Sunan Abi Dawud. India: Sheikh Abul Hasan Nadwi Center

Aswah, S. R. (2017). Antara Ideal dan Praktek: Transformasi Spiritual Anggota Perempuan Berdasarkan Nilai-Nilai Keperempuanan Wahdah Islamiyah. ETNOSIA: Jurnal Etnografi Indonesia,2(2), 177-200. https://doi.org/10.31947/etnosia.v2i2.2582

Chaplin, C. (2018). Salafi Islamic piety as civic activism: Wahdah Islamiyah and differentiated citizenship in Indonesia. Citizenship studies, 22(2), 208-223. https://doi.org/10.1080/13621025.2018.1445488

Creswell, John. (2015). Educational Research, Planning, Conducting, and Evaluating Quantitative and Qualitative, Terj. Helly Prajitno Soetjipto dan Sri Mulyantini Soetjipto, Riset Pendidikan: Perencanaan, Pelaksanaan, dan Evaluasi Riset Kualitatif \&Kuantitatif. Cet.I; Yogyakarta: Pustaka Pelajar.

Departemen Kementrian Agama RI. (2010). Al-Qur'an Tajwid dan Terjemah. Bandung: Diponegoro.

Hibbān, Muhammad Ibn. (2004). Sahih Ibn Hibbān. Beirut: Dārul Ma’rifah.

Hidayat, Anwar. "Cara Hitung Rumus Slovin Besar Sampel”. Official Website of Anwar Hidayat. http://www.statistikian.com/2017/12/hitung-rumusslovin-sampel.html (16 Desember 2017). 
Hasyim, Wakhid. “Arifin Ilham, Poligami dan Paradoks Popularitas", (https://m.detik.com, akses tanggal 10 Mei 2019).

Indrawan, Rully dan Yaniawati, Poppy. (2017). Metodologi Penelitian. Kuantitatif, Kualitatif, dan Campuran. untuk Manajemen, Pembangunan, dan Pendidikan. Bandung; Refika Aditama.

Komnas Anti Kekerasan Terhadap Perempuan. Catatan Tahunan tentang

Kekerasan Terhadap Perempuan. (https://www.komnasperempuan.go.id, akses tanggal 6 Maret 2015)

Mardani. (2016). Hukum Keluarga Islam di Indonesia. Cet. I; Jakarta: Prenadamedia Group.

Muhtadi, Burhanuddin. Mayoritas Pemuda Muslim Menolak Poligami. DetikNews, (Diakses, 25/11/2020).

Musa, 'Iyadh bin. 1998. Ikmal al-Mu'lim Bifawaid Muslim. Darul Wafa'.

Mutiara, Dian Anditya. "Habsyi ungkapkan alasan menikahi Istri keduanya secara diam-diam". Official Website of wartakota tribunnews.com.https://wartakota.tribunnews.com (10 Mei 2019).

Pemita, Desika. Madu dan Cobaan Pernikahan Aa Gym dan Teh Ninih. Official Website of m.liputan6.com. https://m.liputan6.com (10 Mei 2019).

Rahmān, Abu Abdul. (1991). Fạ̣lu Ta'addud al-Zaujāt. Riyadh: Dārul Manār

Rahman, R. A. (2016). Konsep Keadilan dalam Alquran. NUKHBATUL'ULUM: Jurnal Bidang Kajian Islam, 2(1), 167-175. https://doi.org/10.36701/nukhbah.v2i1.12

Ramdani, F., \& Aswar, A. (2020). Hablun Minannas Wanita Bercadar (Studi Fenomenologi Interaksi Sosial Wanita Bercadar di Kecamatan Manggala Makassar). NUKHBATUL 'ULUM: Jurnal Bidang Kajian Islam, 6(1), 105-121. https://doi.org/10.36701/nukhbah.v6i1.114 